OPEN ACCESS

Edited by:

Tathagata Chatterii,

Xavier University, India

Reviewed by:

Miguel Valdez,

The Open University, United Kingdom

Ralph Horne

RMIT University, Australia

Ana Almeida,

Ministry of the Environment, Brazil

*Correspondence:

Beth Perry

b.perry@sheffield.ac.uk

Specialty section

This article was submitted to Governance and Cities,

a section of the journal

Frontiers in Sustainable Cities

Received: 23 July 2021 Accepted: 30 September 2021 Published: 29 October 2021

Citation:

Perry B, Diprose K, Taylor Buck N and Simon D (2021) Localizing the SDGs in England: Challenges and Value Propositions for Local Government. Front. Sustain. Cities 3:746337. doi: 10.3389/frsc.2021.746337

\section{Localizing the SDGs in England: Challenges and Value Propositions for Local Government}

\author{
Beth Perry $^{1 *}$, Kristina Diprose ${ }^{2}$, Nick Taylor Buck ${ }^{3}$ and David Simon ${ }^{4}$ \\ ${ }^{1}$ Urban Institute, The University of Sheffield, Sheffield, United Kingdom, ${ }^{2}$ Formerly of Urban Institute, The University of \\ Sheffield, Sheffield, United Kingdom, ${ }^{3}$ Faculty of Science, The University of Sheffield, Sheffield, United Kingdom, \\ ${ }^{4}$ Department of Geography, Royal Holloway, University of London, Egham, United Kingdom
}

The United Nations' Development Goals (SDGs) have been criticized but are nonetheless seen by many as an important, if imperfect, international effort to address climate and environmental change, resource depletion and the unsustainability of contemporary life. Many of the Goals need to be implemented at the local level, yet sub-national governments have not been granted any enhanced status at the UN to facilitate this process. As a result, the role and effectiveness of local governments in localizing the SDGs is dependent on multi-level arrangements within respective national contexts. In this paper we present findings on the challenges facing local authorities in England, namely co-dependent ambivalence, partial holism and narrow practices of knowledge governance. We draw on work carried out collaboratively with local authorities and other stakeholders in Greater Manchester and Sheffield, and a UK-wide national workshop. These challenges explain the relatively low uptake and engagement with the SDGs in the context of wider political and economic concerns compared with international comparator cities. Against this background our research found that making the Goals real, relevant, relatable and relational offered a tactical route to localization for English local government.

Keywords: sustainable development goals (SDGs), England, local government, localization, sustainable cities, sustainability, Greater Manchester, Sheffield

\section{INTRODUCTION}

During 18 months in 2015-16, United Nations (UN) member states adopted several complementary landmark agreements and agendas, known collectively as the global sustainable development agenda. Although they have different lifespans, each element consolidates and upgrades previous efforts to tackle climate and environmental change, resource depletion and the unsustainability of contemporary life. The key components are the Sendai Framework for Disaster Risk Reduction, Agenda 2030 for Sustainable Development-which includes the 17 Sustainable Development Goals (SDGs), Paris Agreement on Climate Change, Addis Ababa Agreement on Financing for Development, and New Urban Agenda (NUA). Whilst there have been critiques of the SDGs (Swain, 2017; Sultana, 2018), they are seen important if imperfect: an unprecedented global effort-and quite possibly the last chance-to avert catastrophic and irreversible global warming. 
Equally importantly, all these strategies acknowledge that national governments will be unable to achieve the objectives alone and that sub-national entities, such as regional and local governments, will have to play important roles (Barnett and Parnell, 2016; UN, 2017; Blythe et al., 2018; Rudd et al., 2018; Simon et al., 2018). Although the UN, the membership of which is limited to national governments, first recognized the importance of sub-national entities to promoting sustainability at the World Conference on Environment and Development (WCED) in Rio de Janeiro in 1992, through what became Local Agenda 21, this new programmatic emphasis is unprecedented. Yet, as Graute (2016) points out, the UN has not granted regional and local governments any enhanced status at the UN in order to facilitate implementation and monitoring of the agenda. This reflects concerted opposition from some national governments, which were determined to retain their monopoly role. Hence national governments remain the sole formal conduits through their respective national reporting agencies.

This raises several challenges and puts a-perhaps unrealistic-premium on effective multi-level collaborative governance between national regional and local government institutions in each country if the progressive and transformative potential of the SDGs is to be achieved (Leck and Simon, 2013, 2018; Hajer et al., 2015; Castán Broto, 2017; Allen et al., 2018; Koch and Ahmad, 2018; Robin and Acuto, 2018; Bulkeley, 2019). As these authors demonstrate, in practice, national governments often control sub-national governments in top-down fashion, especially in authoritarian systems and where central government provides a large proportion of their operating and capital budgets. There is often a mismatch between statutory responsibilities on the one hand and powers, resources and capacity on the other. Moreover, differences in political control across the levels of government may create tensions or even conflictual vertical relationships. In that context, 6 years since implementation of the global sustainable development agenda commenced in all member states, it is now timely to assess progress with respect particularly to local authorities and in relation to the challenges identified by Graute (2016).

In so doing, we focus primarily on England, UK, examining the specific challenges faced by local authorities in these multilevel arrangements, which explain their lagging position behind counterparts in other European countries and those further afield, some of which have emerged as highly proactive leaders nationally and internationally. In the second section we set out our research design, methods and analytical framework. We draw on an integrative methodology initiated in the UK as part of an international study on the localization of the SDGs, combining interviews, policy mapping, workshops and a commitment to co-productive principles, primarily in the context of the two Northern city-regions of Greater Manchester and Sheffield. The work was undertaken between 2015 and 2019, pre-dating the COVID-19 pandemic in 2021 but coinciding with the Brexit campaign and referendum about the UK leaving the European Union. In the third section of this article, we present the results of our analysis around the three key challenges facing English local authorities in localizing the SDGs in the UK national context: co-dependent ambivalence; partial holism and the narrow practices of knowledge governance. Finally, we identify four value propositions for overcoming these challenges, in the absence of wider systemic governance and policy reform: making the goals real, relevant, relatable and relational.

\section{BACKGROUND AND METHODOLOGY}

The SDGs were adopted in 2015 as part of the United Nations' Agenda 2030, as a successor to the Millennium Development Goals (MDGs). A crucial difference between the two sets of goals is that the MDGs focussed on challenges for 'developing' nations, while the SDGs are universal, recognizing that countries with a high GDP per capita also have work to do to address inequalities between rich and poor, improve quality of life, and respond to the climate crisis. The SDGs comprise 17 Global Goals (see Table 1), underpinned by 169 targets and 232 indicators for measuring progress to 2030. They have been officially adopted by 193 countries and are an urgent call to action to end poverty, protect the planet and ensure prosperity for all. Goal 11, on Sustainable Cities and Communities (see Table 2), and the urban-related components in most of the other Goals, are also now being deployed as monitoring and evaluation tools for assessing progress on the NUA (U. N. Habitat, 2020).

In 2015 an international center for sustainable urban development, Mistra Urban Futures (MUF), undertook a pilot project to test the then-draft targets and indicators for the urban SDG in five cities-Greater Manchester (England), Cape Town (South Africa), Gothenburg (Sweden), Kisumu (Kenya) and Bengaluru (India) — and tested the data availability, relevance and appropriateness of the draft targets and indicators for Goal 11 (Simon et al., 2016; Arfvidsson et al., 2017). On the basis of this work, a set of recommendations was produced, some of which were taken up by the UN statistical team in the Department of Economic and Social Affairs (UNDESA) in finalizing the targets and indicators. In 2017 a larger comparative research project was initiated with seven participating cities: Sheffield (UK), Buenos Aires (Argentina), Cape Town (South Africa), Gothenburg and Malmö (Sweden), Kisumu (Kenya), and Shimla (India). The project aimed to research and support local understanding of the SDGs and NUA; facilitate cross-city knowledge exchange and provide feedback to ongoing UN revisions of these initiatives. A key difference between the pilot study and larger comparative project was the focus on data availability (pilot study) vs the wider localization agenda (comparative project).

The research followed a transdisciplinary methodology, involving partnerships between local research teams and municipalities in each city (Valencia et al., 2019, 2020). This approach was at the heart of the Mistra Urban Futures center, on the basis that the knowledge and skills required for sustainable urbanization does not lie within single organizations or sectors (Polk, 2015; Hemström et al., 2021). In each of the cities, the project involved co-investigators from local government and academia, mediated through Local Interaction Platforms or more limited formal partnership agreements (Perry et al., 2018) and research briefs were translated to take local priorities into account within an overall comparative framework. This meant that whilst 
TABLE 1 | The sustainable development goals.

\begin{tabular}{|c|c|}
\hline Goal 1 & End poverty in all its forms everywhere \\
\hline Goal 2 & End hunger, achieve food security and improved nutrition, and promote sustainable agriculture. \\
\hline Goal 3 & Ensure healthy lives and promote well-being for all at all ages. \\
\hline Goal 4 & Ensure inclusive and equitable quality education and promote life-long learning opportunities for all. \\
\hline Goal 5 & Achieve gender equality and empower all women and girls. \\
\hline Goal 6 & Ensure availability and sustainable management of water and sanitation for all. \\
\hline Goal 7 & Ensure access to affordable, reliable, sustainable, and modern energy for all. \\
\hline Goal 8 & Promote sustained, inclusive, and sustainable economic growth, full and productive employment, and decent work for all. \\
\hline Goal 9 & Build resilient infrastructure, promote inclusive and sustainable industrialisation and foster innovation. \\
\hline Goal 10 & Reduce inequality within and among countries. \\
\hline Goal 11 & Make cities and human settlements inclusive, safe, resilient, and sustainable. \\
\hline Goal 12 & Ensure sustainable consumption and production patterns. \\
\hline Goal 13 & Take urgent action to combat climate change and its impacts. \\
\hline Goal 14 & Conserve and sustainably use the oceans, seas, and marine resources for sustainable development. \\
\hline Goal 15 & $\begin{array}{l}\text { Protect, restore, and promote sustainable use of terrestrial ecosystems, sustainably manage forests, combat desertification, and halt and reverse land } \\
\text { degradation and halt biodiversity loss. }\end{array}$ \\
\hline Goal 16 & $\begin{array}{l}\text { Promote peaceful and inclusive societies for sustainable development, provide access to justice for all and build effective, accountable, and inclusive } \\
\text { institutions at all levels. }\end{array}$ \\
\hline Goal 17 & Strengthen the means of implementation and revitalize the global partnership for sustainable development. \\
\hline
\end{tabular}

TABLE 2 | Goal 11 "Make cities and human settlements inclusive, safe, resilient and sustainable."
11.1
By 2030, ensure access for all to adequate, safe and affordable housing and basic services and upgrade slums.
11.2 By 2030, provide access to safe, affordable, accessible and sustainable transport systems for all, improving road safety, notably by expanding public transport,
with special attention to the needs of those in vulnerable situations, women, children, persons with disabilities and older persons.
11.3 By 2030, enhance inclusive and sustainable urbanization and capacity for participatory, integrated and sustainable human settlement planning and management in all countries.
11.4 Strengthen efforts to protect and safeguard the world's cultural and natural heritage
11.5 By 2030, significantly reduce the number of deaths and the number of people affected and substantially decrease the direct economic losses relative to global gross domestic product caused by disasters, including water-related disasters, with a focus on protecting the poor and people in vulnerable situations.
11.6 By 2030, reduce the adverse per capita environmental impact of cities, including by paying special attention to air quality and municipal and other waste management.

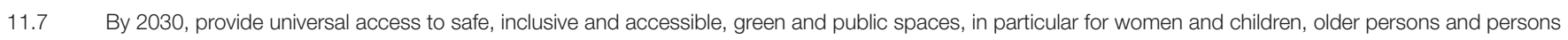 with disabilities
11.a Support positive economic, social and environmental links between urban, peri-urban and rural areas by strengthening national and regional development planning.
11.b By 2020, substantially increase the number of cities and human settlements adopting and implementing integrated policies and plans towards inclusion, resource efficiency, mitigation and adaptation to climate change, resilience to disasters, and develop and implement, in line with the Sendai Framework for Disaster Risk Reduction 2015-2030, holistic disaster risk management at all levels.
11.c Support least developed countries, including through financial and technical assistance, in building sustainable and resilient buildings utilizing local materials

questions and concerns were shared across city partners, methods diverged depending on local interpretation (Simon et al., 2020; Valencia et al., 2020).

In the UK the project worked across two city-regions in the North of England: Greater Manchester (GM) and Sheffield-the locations of the lead collaborating institutions in MUF (first, the SURF Center, University of Salford; then the Urban Institute, University of Sheffield). The design of the Center itself was predicated on the potential of university-city partnerships in 'ordinary', secondary cities to co-produce knowledge to meet urgent and complex urban challenges. The choice of sites was therefore driven by antecedent structural decisions, rather than a purposive or theoretical set of sampling criteria. Nonetheless the two sites are interesting in the English context. The study of Greater Manchester enabled insights into the dynamics of SDG localization in a large, newly emerging city-regional context, characterized by cross-local authority arrangements and a history of collaborative working; whilst Sheffield provided evidence of a medium-sized unitary authority, operating within the constraints of local government arrangements in England. It is relevant to note that our studies were, at the time, the first engagement with the SDGs for both contexts.

Greater Manchester was the site for the first phase pilot study, which involved a collaboration between academics and an environmental consultancy to identify the gaps between required and existing data to report on the SDGs and undertake some pilot data collection. The study involved a collaborative workshop with 12 representatives from Greater Manchester Low Carbon 
Hub, who helped facilitate access to other participants, such as local authorities (Manchester, Salford, Stockport, Rochdale, and Bury), the water and energy company and the civil contingencies and resilience unit. Workshop participants selected the specific targets for which they were interested in gathering data to test the relevance of the SDGs locally (environmental impact: 11.6, housing: 11.1, disasters: 11.5 and transport: 11.2). The project team then undertook an audit of data sources and identified data gaps through meetings and consultations with key data providers, using a snowball methodology. In total 25 people were involved in the data mapping, from 21 organizations, including at national level (the Office for National Statistics, the Department for Transport and the Department for Communities and Local Government), with local authorities and stakeholders, businesses, the Environmental Agency or police.

Following the pilot project, Greater Manchester was invited to continue with the project in a comparative mode alongside a second site in Sheffield. Whilst GM participants in the pilot project reported that they valued being involved, due to the prestige of the international collaboration, and the opportunity to increase awareness of UN initiatives, there were a number of reasons why they decided to withdraw. In particular, there was a high level of governance flux and uncertainty, with the city-region on the cusp of governance change following the City Deal agreed with central government which would lead to a new Combined Authority across local authority boundaries (Coleman et al., 2016; Colomb and Tomaney, 2016). There was also a sense that the SDGs did not offer a useful framework for action. On several targets, GM felt they exceeded the target levels specified, whilst a number of others were seen as out of scope or lacking basic data. These reasons mirror the very challenges of localization we highlight in this article.

In Sheffield, a new collaboration was established between researchers and Sheffield City Council (SCC). This involved desk-based research, stakeholder interviews, and a stakeholder workshop. A review of local strategies published by Sheffield City Council, Sheffield City Region, Sheffield City Partnership and others was carried out to identify where local ambitions aligned with SDG targets. Between July 2017 and August 2019, we conducted 18 interviews with 22 individuals (some of whom were interviewed together). This included city officials working in energy, flooding, health, housing, infrastructure, planning, sustainability and transport, a local councilor, representatives from both city universities, and from civil society and the private sector. These interviews explored local awareness of the SDGs, views on their relevance to Sheffield and, as the research progressed, sought feedback on the pilot work undertaken for SCC. Each interview was digitally recorded and transcribed. The interviewees were identified collaboratively between SCC and academic researchers, with invitations issued from the lead officer for sustainability in the local authority. Criteria for selection related to those with a 'sustainability' mandate within the city, broadly interpreted, as well as the desire of SCC to use the project to catalyze discussions and build capacities for crossorganizational working.

Working closely with a network organization called UK Stakeholders for Sustainable Development (UKSSD), the authors organized a national 'Localizing the Sustainable Development
Goals' workshop for local authorities in June 2019. The workshop was attended by 28 people, including representatives from eight local authorities, three city regions, voluntary sector and civil society organizations and a local SDG 'hub', from the Local Government Association, and international guests from the cities of Baltimore (remotely), Gothenburg and Utrecht. Notably, our Greater Manchester policy contact from the pilot study was present, which enabled comparative insights to be introduced to the workshop. This workshop was reportedly the first time that UK city participants had an opportunity to come together to share their experiences of working with the SDGs and ideas for action. Attendees were, by invitation, those local authorities and city stakeholders that had been more engaged in working with the SDGs, and they thus tended to have a higher level of familiarity with the framework than the Sheffield local authority stakeholders we interviewed. In line with our commitment to co-produce outputs for different audiences and achieve impact, we produced a policy brief and shared a series of online materials, such as videos and resources, to help local authorities think through the importance and implications of the SDGs. We also sought to influence policy discussion, for instance, through submitting evidence to the UK Environmental Audit Committee, writing internationally-oriented policy briefs, undertaking comparative analysis with other cities, and engaging local authorities and national actors in bilateral discussions.

In developing our analytical framework, set out below, in the context of the wider international comparative study, we wanted to understand why there was less engagement and awareness around the SDGs in either Greater Manchester or Sheffield compared with the cities outside the UK. In Kisumu, SDGs were mainstreamed within the development plans and County Integrated Development Plans, then cascaded into the Annual Development plans with budget lines. Directly addressing SDG Target 11.1, extra funding was acquired to develop over 2,000 affordable housing units through private public-partnership arrangements and direct funding from the national government. Malmö developed a five-step strategy for localizing Agenda 2030. In the new city budget for 2020, the global Goals were intended to be aligned with the Goals for the city, thus providing a unified framework for prioritizing. A new local coastal strategy for implementing SDG 14, Life below Water, was also the direct result of Agenda 2030. In both Buenos Aires and Cape Town, the 100 Resilient Cities strategies provided opportunities for the cities to prioritize the topic of resilience (Croese et al., 2020; Valencia et al., 2021). The city of Buenos Aires also presented a Voluntary Local Review (VLR) to the UN in 2019, outlining the city's priorities. Cape Town and Malmö committed in 2019 to present VLRs and these are being finalized during 2021. In Cape Town and Buenos Aires, a focus on the SDGs helped focus on housing issues in the cities. Yet in Greater Manchester and Sheffield, to our knowledge, no further work took place on the SDGs since our study.

\section{ANALYTICAL FRAMEWORK}

Our research design and methods generated the following data sources for each of the two city sites, as well as the comparative workshop: notes of meetings, interview transcripts, workshop 
reports and materials (including post-it notes, videos, and online collaborative spaces), policy briefings and research reports. Data also included documentary analysis of policies and strategies, particularly in Sheffield. The project was not, however, designed as a comparative case analysis (cf. Yin, 2014), rather a process of transdisciplinary engagement in two discrete sites where the insights and limitations of the pilot study already influenced the design and implementation of the larger comparative study. We therefore treated the data as a single national, rather than two separate 'Greater Manchester' and 'Sheffield' case-based datasets, within the context of a strategic research design rather than a mixed-methods study (Stoecker and Avila, 2020).

Our study followed neither a pure hypothetical deductive reasoning, nor a fully grounded theory approach (cf. Bryant and Charmaz, 2010), moving back and forth abductively between theory and data. Our prior analytical concepts and hunches around 'localisation' as a relational process guided our analysis (May and Perry, 2018). Drawing on literatures around multi-level governance (i.e., Hooghe and Marks, 2003; Bache and Flinders, 2004; Leck and Simon, 2013; Bulkeley, 2019), policy integration (i.e., Hajer et al., 2015; Nilsson et al., 2016; McGowan et al., 2018) and local data politics (i.e., Barnett and Parnell, 2016; May and Perry, 2016; Klopp and Petretta, 2017; Koch and Ahmad, 2018), we were interested in three sets of relations: between levels of governance (international/national/local), between actors in the urban space, especially those aligned with different SDGs, and between quantitative and qualitative forms of data, knowledge and expertise. Put simply, we framed localization of the SDGs as mediated by governance structures, cross-sectoral and policyspecific concerns, and available data and expertise, aligned to targets and indicators.

In this context, researchers analyzed the dataset to identify arising themes and congruous and divergent data. Given the heterogeneity of our data across two sites, arising from a transdisciplinary process of co-production, we decided not to use computer programmes to aid the analysis; instead, the process of qualitative and manual thematic analysis was preferred to enable process-based reflections to interact with the data, with a focus on patterns of meaning around our key themes (Guest et al., 2012). Using different researchers to undertake analysis, and collaborative discussion to check for inter-researcher reliability, was undertaken as good practice to ensure consistency (Joss et al., 2017; Hersperger et al., 2020). Following this process, moving between data arising from different sources and existing literature, we identified the three key themes which we use to analysis the data below.

Our commitment to a transdisciplinary research design with and for stakeholders responsible for implementation meant that we needed to move 'beyond critique' (Perry and Atherton, 2017). Our data help explain why local authorities lack resources and agency, and how the implementation of the SDGs is stalled by ambiguities in multi-level governance. In the absence of a statutory framework for localizing the SDGs, with no clear responsibilities or resources devolved to local authorities, what then does this mean for how English local authorities orient themselves to the SDGs, especially in the context of cuts to public funding as a result of austerity policies? We draw on de Certeau's
(1984) distinction between strategies and tactics to help address this question, where strategies are formulated from a position of power, whilst tactics operate in the absence of formal power. Although not technically power-less in terms of an absence of spaces of authority, local authorities have to make choices about whether, in the context of a dominant and established order, engagement with the SDGs is valuable. The value of localization in the English context therefore rests on whether tactically, it is possible to mobilize the SDGs for wider purposes. This is the context in which we develop, in our discussion and conclusion, the idea of the value proposition-as a way for local authorities to assess the cost-benefit of working with the SDGs and to think tactically about their use value in their own spatial contexts.

Before returning to this question of value propositions, we set out our findings under the three key challenges of co-dependent ambivalence; partial holism; and the narrow practices of knowledge governance which were identified through the integration of theory and data.

\section{CO-DEPENDENT AMBIVALENCE}

Like in many countries, the extent to which British local authorities can implement the SDGs is determined in part by the nature of central-local relations and levels of decentralization or devolution (Jones and Ward, 2002). The UK is one of the most highly centralized of all OECD countries (Hambleton, 2017). Since the late 1990s a process of regionalization was followed by a focus on the city-regional scale, with the development of multiactor governance structures across local authority boundaries. City-regions began to enter into bilateral 'city deals' with central government to secure devolved powers and responsibilities, granted on the basis of strong cross-boundary partnerships and certain imposed conditions (such as the direct election of a city-regional mayor).

In 2015 at the time of our first study, decentralization efforts in England were seen to have 'failed' to address issues of democratic disaffection and exclusion (Blunkett et al., 2016). Scholars were concerned about a risk of greater spatial differentiation and inequality (Waite et al., 2013) in a system which presumed that city-regional authorities and councils can 'earn autonomy' if they follow the rules set down by central government (Tait and Inch, 2015). In practice, this means that in England, more than in federal systems or quasi-autonomous regions, there is limited and variable capacity or capability to act independently of central government. This co-dependence, in relation to the SDGs, both exists in and produces a state of ambivalence.

The UK Government was a leading architect of the SDGs and, like other UN member states, has committed to achieving them at home and abroad (Hickson, 2015). In June 2019, the Government submitted its first Voluntary National Review (VNR) of progress toward the Goals and the then-Secretary of State for International Development, Rory Stewart, presented this at the UN High Level Political Forum in New York the following month. The Office for National Statistics (ONS) is responsible for measuring the UK's progress toward the SDGs and published a report of progress made toward measuring SDG indicators in November 2018. The 
ONS is currently reporting on $75 \%$ of the SDG indicators on a UK National Reporting Platform, and the UK is among the world leaders in publishing open data on the SDGs.

Despite these promising signs of national level commitment, 6 years since the adoption of the SDGs the UK Government has yet to produce a national implementation plan. Two cross-party reports by the House of Commons International Development Committee, UK implementation of the Sustainable Development Goals (House of Commons International Development Committee, 2016; House of Commons, 2019) and UK progress on the Sustainable Development Goals: The Voluntary National Review (2019), and two by the Environmental Audit Committee, Sustainable Development Goals in the UK (House of Commons Environmental Audit Committee, 2017) and Sustainable Development Goals in the UK follow up (House of Commons Environmental Audit Committee, 2019) highlighted serious shortcomings in the UK Government's approach to national SDG implementation. These shortcomings included: a failure to take the SDGs seriously as a domestic policy agenda, a problem that has been reinforced by the Department for International Development (DfID) having lead responsibility for the Goals; insufficient communication, understanding and coordination of the Goals across all Government departments; poor and lastminute stakeholder engagement activity to produce the UK VNR and a selective and partial VNR which was criticized for being overly positive and providing ungrounded emblematic examples.

The VNR outlined the Government's view that the SDGs are addressed primarily through existing policy mechanisms, such as Single Department Plans. However, the Environmental Audit Committee's 2019 report concluded that this approach had proved ineffective:

\section{"In their present format, Single Departmental Plans are insufficient to deliver the SDGs and the UK. Government's failure to ensure that all SDG targets are covered in the SDPs has left significant gaps in plans and accountability." (p. 4)}

Independent analysis by a cross-sector group of over 100 organizations, conducted in 2018 for the UKSSD report 'Measuring Up' [UK Stakeholders for Sustainable Development (UKSSD), 2018], suggested that the UK was performing well on less than a quarter $(24 \%)$ of the targets that underpin the SDGs. Altogether, this evidence indicated that the UK Government could do much more to demonstrate its commitment to the Goals and to support effective action by all sectors of society. National participants expressed their hope that the subsequent publication of the UK VNR would act as a launch pad for greater action on the SDGs in the following months.

This national ambivalence is not surprising for a UK government that, prior to its agreement to host the COP26 summit in November 2021, has shown variable support for action on climate change and sustainable development (Hulme and Turnpenny, 2004; Carter, 2008). The wider political discourse at the time of our study was dominated by Brexit and the ongoing and deep-seated impacts of a decade of austerity policies (TaylorGooby, 2012; Fuller and West, 2017; Hastings et al., 2017). This environment both shaped the way in which action on SDGs was framed, and the extent to which local government had any resources to respond.

\section{Local Engagement and Awareness}

At our workshop, attendees from Scottish local authorities highlighted how, in their case, the Scottish Government had emphasized the link between the SDGs and Scotland's National Performance Framework and Outcomes, and how, in 2018, the SDG Network Scotland wrote to all Scottish local authority chief executives asking them to demonstrate their commitment to the SDGs. This level of guidance has been absent in the rest of the $\mathrm{UK}$, and as a result the SDGs have had a higher profile in Scotland both nationally and locally.

Explicit efforts to engage local authorities in the SDG agenda in England have been minimal. As part of the VNR process, DFID hosted two local stakeholder engagement events in Bristol and Leeds, and the Ministry of Housing, Communities and Local Government (MHCLG) hosted a London roundtable event focused on Goal 11, but these events were organized on very tight timescales, and few local authorities were able to attend as only a few days' notice was given. In June 2019 our workshop was said to have been the first time that local authorities had been able to discuss common challenges and contexts for SDG implementation.

In July 2019, a motion was passed at the Local Government Association (LGA) General Assembly calling on the Government to: (i) explore supporting domestic implementation of the SDGs through funded partnership roles within each local authority area; and (ii) encourage councils to continue their work linking their local priorities with the overall ambitions of the SDGs. Additionally, the motion declares a climate emergency and commits the LGA to supporting councils in their work to tackle climate change.

The SDGs are not aimed specifically at local authorities or city level actors, but as with the entire current global sustainable development agenda, these actors are crucial to their successful implementation. It is estimated that around two thirds of the SDG targets will need to involve urban stakeholders (IIED for the Cities Alliance, 2015). This is recognized locally, as one policy officer at our workshop stated:

"Two thirds of what needs to happen to fix the planet can only happen locally...there's a fundamental role for place, and community and people, and that really can only happen where we live." (Officer, Bradford Council)

Accordingly, the LGA called on the Government to support domestic implementation of the SDGs through funded partnership roles within each local authority, and to encourage councils to pursue work linking local priorities with the SDGs.

However, despite these limited moves, local authorities-in a co-dependent relationship with central government-reported being unsure about the relevance of the SDGs given the lack of tangible national commitment. As noted above, our workshop largely attracted those already interested in the SDGs, such as one representative of the London Sustainable Development 
Commission who noted that the SDGs were a galvanizing framework and that:

\begin{abstract}
'The dynamics between the various global Goals are visible at a city level. The levers to address them are frequently within the remit of coordinated city authorities.' (Officer London Sustainable Development Commission)
\end{abstract}

However, within Sheffield our interviews revealed that many local stakeholders had either not heard of the SDGs at all $(n=8)$, or described them as something they were "vaguely" or "superficially" aware of:

"I don't think I'm unusual in any local authority in saying this hasn't yet crossed my path" (Local authority workshop participant).

Those with some awareness of the SDGs tended to know one or two high level details, such as them being an international framework, a successor to the MDGs, and perhaps some of the Goals, rather than having a detailed understanding of the holistic framework and its underpinning targets. Some participants highlighted a misconception that the SDGs are, like the MDGs, more focused on international development challenges and issues of basic human need in developing countries. The terminology of 'development' and the visibility of DFID as the lead Government Department for the SDGs reinforced this perception:

"DfID is a department that we have absolutely no contact with at all... If it [guidance or consultation] had been produced by [MHCLG] or BEIS, absolutely it would be on our radar and we'd be aware of it, but DfID is aid and international development and all that stuff, and it's just not relevant to us generally. So it's something about where it's positioned and how it gets translated (Local authority representative, workshop)."

Moreover, because the MDGs were not considered relevant to the UK, there was no legacy of national and local partnership for development to build upon. When the SDGs were framed as a continuation of the MDGs, it affirmed the view that they are of limited domestic relevance.

Only three of the stakeholder interviewees, none of whom worked in local government, were aware of UK Government activity around the SDGs. Local government and city region officials were unsure of the national status of the SDGs and the extent of the Government's commitment to them, and they had not come across any explicit references to the SDGs in the policy frameworks and funding criteria that they work with day-to-day. Some participants highlighted how the visibility-or invisibility-of the SDGs was perhaps a question of the level at which they are aimed:

"Do you assume that national policymaking is taking advantage and note of international frameworks such as this, or do you have to make the assessment of, has national done that job and do I need to do that job?" (Officer, Doncaster Council)

"... if the national Government isn't aligned or at least we don't know that they're aligned, then it's difficult to align ourselves." (Officer, Sheffield City Region)
None of the local government and city region participants that we interviewed was aware of the UK VNR-ongoing at the time of our research-or of opportunities to contribute to the VNR through consultation.

\section{Devolving Responsibility Without Resource}

The consequence of uncertain and ambivalent national support for implementing the SDGs, coupled with low levels of local awareness, is a devolution of responsibility from central to local government in the context of competing demands and dwindling resources. England has been "a landscape of almost permanent administrative reconfiguration [...] during the last 50 years" (Ayres et al., 2018: p. 863). During the 2010s, this manifested in the 'devolution agenda' in which English city-regions developed City Deals with central government in exchange for enhanced powers and responsibilities. In an era of widespread "austerity urbanism" (Peck, 2012), however, devolution has gone hand-inhand with dramatic reductions in funding for local authorities, impacting the most vulnerable (Hastings et al., 2017).

National policies were perceived to undermine local efforts to advance sustainable development. Greater Manchester and Sheffield's experiences were not unique, in a UK national context of mostly Labour (opposition) led urban local authorities and a national Conservative Government. The impact of national austerity policies on local government budgets and thus the resources available for sustainability personnel and programmes was highlighted as a major challenge by most of the local stakeholder participants that we interviewed:

\footnotetext{
"... it is worth noting the significant reduction in spending power of local government over the past seven or eight years. The precise number varies from place to place, but; it is often characterised... as a reduction of $60 p$ in every $£ 1$ of spending power... This has had a significant bearing on local government's ability to provide many services and, given staffing reductions, on the sector's ability to continue to develop programmes, services and policies in this space. It is probably not mentioned frequently nationally, but it does matter... it matters a lot." (Officer, Sheffield City Council)
}

As a result of austerity policies, even those local authorities interested in implementing the Goals had inherited understandable ambivalence about their usefulness. This led to the need to assess the potential value of the Goals against other potential frameworks or policy initiatives:

\begin{abstract}
"You've got to be careful when you start ramping up the focus on a certain framework because there's often a lot of rivals out there. [There are] a lot of pragmatic implications, in terms of how we assess the importance of these different frameworks. What's the business case we're going to put behind this and to what end? What, in tangible terms, are we going to be gaining from this, whether that's new thinking or funding or networks and linkages? At the moment, it feels unclear." (Officer, Doncaster Council)
\end{abstract}

This participant was one of several considering the relative value of a 'wealth of indicators and indices' spanning different policy areas at the national level, some more obviously aligned with national policy frameworks. 
The ever-changing and uncertain national policy landscape, compounded by negotiations on the terms of the UK's exit from the European Union, created a challenging climate for making progress on the SDGs at a local level. Local authority officers in Barnsley, Doncaster and Sheffield felt that such work would only gain traction if the SDGs were being championed at a senior level and among their local politicians-a factor identified in the comparative research as well (e.g., Patel et al., 2017; Valencia et al., 2019). Whether or not this championing occurred was the result of how well-aligned the SDGs were seen to be with existing local priorities, as we shall now discuss.

\section{PARTIAL HOLISM}

The ambivalence produced through national-local codependence has produced a second challenge in localizing the SDGs which we call partial holism. The SDGs were always intended as a holistic framework, in the words of one participant:

"a framework to galvanise political, business, and other society interests in delivering things that will improve people's quality of life" (Officer, London Sustainable Development Commission).

This holism is reflected in recognizing that, although there is a single SDG, Goal 11, for 'Sustainable Cities and Communities', a number of the Goals have relevance at the city scale. An assessment by the IIED for the Cities Alliance, 2015 highlights implicit links between the urban-focussed Goal 11 and other SDGs, concluding that, whilst the SDG targets rarely assign specific responsibilities to 'local' and 'city' level actors, around two-thirds of the targets in all 17 Goals ought to involve urban stakeholders. Local authorities need to engage beyond Goal 11 to overcome sectorsemia (May and Perry, 2016):

"It's incredibly easy to fall into silos because it's almost the norm, isn't it? It takes effort to work out of the silo, but perhaps if you had a framework to do that, it's almost like an audit process... a framework that says, 'Just be careful, there may be opportunities here' [...] there may be ways of co-investment, for example, in things that deliver the same aim and maybe better, getting better benefit." (Officer, Sheffield Council)

Guidance on which of the 169 targets are relevant to the work of local authorities and their city partners has been produced by United Cities and Local Governments (UCLG) and by the United States Urban Institute (Greene and Meixell, 2017), which identified three criteria for assessing which SDG targets were not relevant to cities in the global North, namely those:

- explicitly limited to developing/least developed countries.

- explicitly limited to laws, regulations or policies that are exclusively managed by higher levels of government e.g., international treaties, financial regulation.

- addressing sustainable development issues that typically occur outside of urban contexts e.g., large scale agricultural production, marine conservation.
Whilst there are differences between the UK and US policy contexts in terms of decision-making and the regulatory and financial leverage of different tiers of government, pilot work in Bristol illustrated that these criteria can be helpful for identifying SDG targets of relevance to British cities (Carden-Noad et al., 2017).

On this basis, we identified 89 SDG targets that were locally relevant to Sheffield, around $53 \%$ of the total. We then undertook a desk-based review of 30 local strategies published by Sheffield City Council, Sheffield City Region, Sheffield City Partnership and others, to identify where local ambitions align with these targets. Of the 89 SDG targets that we assessed as relevant or potentially relevant to Sheffield, there is local policy coverage of at least 61 . As well as assessing the number of targets that were relevant to Sheffield and local policy coverage, our analysis also considered how interlinkages between the SDGs manifested in local strategies. Yet this alignment of SDG targets and local policy was not a result of local efforts to demonstrate commitment to the SDGs. None of the local strategies that we reviewed explicitly referenced the SDGs; indeed, many of these documents were published prior to the adoption of the SDGs by the UN. Rather, what our analysis demonstrated is that the SDGs are, to a large extent, focused on common challenges that city-level actors have, independently, identified as a local priority and are addressing through local action.

Participants felt that the SDGs covered issues and policy portfolios that mattered to Sheffield, and that there's "nothing disagreeable" within the Goals laid out. Many participants felt that the benefit of the Goals was precisely in retaining this holism:

\begin{abstract}
"Some real thought has gone into these, that's the point. I would challenge anybody to find an area that isn't covered within the Goals... You've got that overarching policy to hang it on, rather than trying to reinvent the wheel. We don't have time to reinvent an overarching holistic policy for changing our society." (Sheffield Green City Partnership Board member).
\end{abstract}

The SDGs should not be viewed as a fixed 'accounting' framework, whereby ticks or crosses are entered into spreadsheets to demonstrate compliance with particular indicators, and with bland reports being produced to justify inaction in many areas. Yet, in practice, several factors made it hard to retain a commitment to holism. First, our research found that the scope and complexity of the SDG framework is a challenge for knowing how to implement it at a local level; in other words, how sustainable development as a concept can "actually translate into local impact." As an example of the complexity of the Goals, interviewees noted the difficulty in identifying where local work around flooding sits within the SDGs, as it can cross various boundaries relating to sustainable cities, public health, climate change adaptation, disaster planning, water management, and blue-green infrastructure. Others observed that any local authority will have "a long list of policies and strategies" that cut across various aspects of the SDGs, and understanding these interrelationships was a challenge: 


\begin{abstract}
"As soon as you scratch the surface of the Goals and try and implement them practically on a project, it becomes evident there are a lot of complexities to them. For example, the Goals, their targets and their indicators give slightly different messages on scope, different stakeholders have different priorities which can alter through the project, measurement of impact is problematic and all the Goals interrelate a great deal." (Officer, Sheffield City Council).
\end{abstract}

Many participants in our project observed a tension within the SDGs between the "push for growth" alongside Goals focused on climate action, environmental protection and tackling inequality. They highlighted how economic growth can have an adverse impact on carbon emissions, environmental quality and health, and how growth does not necessarily go hand-in-hand with decent job creation when new jobs, for example low paid and zero-hours contracts, are precarious. Other tensions noted included between those Goals on democratic participation and climate change: for instance, the idea that, if climate change were seriously at the top of the agenda, this could lead to policies that restrict or penalize certain choices-say, driving a car-that would likely prove unpopular. Participants observed that one of the advantages of the SDGs, if used as a holistic framework, is that they give you a structure "where those trade-offs become really apparent" and therefore a place where trade-offs can be discussed and good compromises reached, rather than always prioritizing economic growth at the expense of other, equally important, Goals. Similar issues about tensions and trade-offs were identified in the 2015 pilot project and from other cities participating in this project (Simon et al., 2016; Arfvidsson et al., 2017; Patel et al., 2017; Valencia et al., 2019, 2020), as well as being reported more widely (e.g., Nilsson et al., 2016; McGowan et al., 2018).

Accordingly, participants in our project were clear that "SDGwashing" should be avoided, as the SDGs were "not intended as a menu of options" and "cherry-picking Goals" was undesirable. Although a benefit of working with the Goals as a coherent framework was seen to be in enabling tensions and trade-offs between different policy objectives to be made visible, in practice, in a context of co-dependent ambivalence and reduction in resources, the pressure was to prioritize between Goals, selecting one or two which align with existing agendas. This chimes with lessons from the comparative project (Patel et al., 2017; Valencia et al., 2019, 2020) and beyond that municipalities are identifying and prioritizing those Goals and targets that align most closely with their existing priorities and initiatives.

At the same time, research participants noted that the overall 'urban' SDG 11 is too broad and "could almost capture everything." They welcomed the focus on access in several of the targets, which is about ensuring not only that urban infrastructure is there, but that it is for everyone's benefit. One stakeholder observed that, despite having 'communities' in the title of the Goal, the underpinning targets are not especially focused on people or enabling communities; rather they focus on processes, buildings and infrastructure. Similarly, another stakeholder felt that the role of culture in place-making should be much more prominent, rather than subsumed under a target about 'the world's natural and cultural heritage'.

\section{Local Translation and Adaptation Necessary}

Given that SDGs were designed primarily with and for national actors, but that the city scale is important for implementation, localization requires an investment of time and resource in translation and adaptation. Local authority officers in our project who were already working with the Goals reported that the SDGs had been useful for several reasons. Participants envisaged the benefits of engaging with the SDGs at a local level to include using them as a communications tool with colleagues and citizens; drawing on the international status and provenance of the SDGs to highlight ambitions for transforming cities; cross-referencing strategies in development and identifying gaps; combating silo thinking; encouraging partnerships; using them as a basis for developing local targets; and demonstrating progress toward holistic sustainability.

Of these, the usefulness of the SDGs as a communications tool was the most commonly highlighted benefit, aligning with views that the SDG framework is best approached 'as a 'proxy' and policy tool, a way to simplify critical issues for the purposes of clarity and activism' (Klopp and Petretta, 2017: p. 96). The SDG icons were perceived as "easy to digest" and, as a whole framework, helpful for explaining the different dimensions of sustainability and how various partners within a city can work together to achieve common Goals:

"Sustainable development as a concept... it's quite big picture for a lot of people. So breaking it down into different Goals makes it a lot easier for people to see how they're contributing." (Representative, not-for-profit energy organization)

For Sheffield, it was quickly decided to focus on more 'traditional' environmental sustainability Goals for the research project, and then, on the wider climate emergency. During the life of the project, Sheffield City Council, along with many other UK local authorities, declared a climate emergency and announced intentions to bring forward zero carbon ambitions and host a citizens' assembly. However, in stakeholder interviews, a key issue was that there was no zero-carbon ambition in the SDGs. Goal 7 on Energy and Goal 13 on Climate Action both predate the latest IPCC reports and, being aimed at all countries, employ somewhat vague targets such as 'increasing the share of renewable energy' and 'improving climate change mitigation', with the level of carbon reduction required presumably to be defined at the national level in line with UNFCCC commitments.

Nonetheless, a priority was to mobilize the SDGs to respond to the climate emergency, in part in recognition that public interest in climate change was high and represented an opportunity to "embed sustainability in what we do" as "the hook upon which we achieve a little bit more traction." Mirroring discussions in the existing literature (Ansuategi et al., 2015; Reckien et al., 2017; Sánchez Rodríguez et al., 2018), other interviewees suggested that the SDGs could help to communicate the importance of a just transition, to "make sure that you're responding to the climate emergency across the board rather than it being restricted to certain socioeconomic classes or certain areas of the city" (Sheffield Green City Partnership Board interview). 
In Greater Manchester, although local stakeholders declined to participate in the second phase of our work, they collaborated with us again on a different project looking at the relevance of SDG 16, and particularly around 'meaningful participation' and 'co-production' (Perry and Russell, 2020). Through this work we collaborated with the recently established Greater Manchester Combined Authority (GMCA) to explore the meaning and relevance of the SDG 16 target on 'ensuring responsive, inclusive, participatory and representative decision-making at all levels', as well as the NUA commitment to:

“... promoting institutional, political, legal and financial mechanisms in cities and human settlements to broaden inclusive platforms, in line with national policies, that allow meaningful participation in decision-making, planning and follow-up processes for all, as well as enhanced civil engagement and co-provision and co-production." (UN, 2017: 14, para 41. Emphasis added)

The work included workshops, interviews and international learning exchanges with other cities. The reason why GM participated in this parallel study, instead of the one that forms the main basis of this article, is that this aligned with political commitments made by the new mayor, elected in 2016, who had stated "that for real change...you need to involve people in the co-production of services and government' (Burnham interview, Taylor, 2017: p. 23).

What we see here is a partial holism, in which the aspiration to use the Goals as an integrated framework is realized, not through implementing each and every urban goal, but by looking at a particular policy issue through a more relational and cross-issue lens. This is part of a local calculation about what will 'land' publicly and politically in different contexts. In Sheffield, the focus on the climate crisis, or in Greater Manchester the focus on meaningful participation, provided an entry point for then deploying the SDGs as a framework for more integrated analysis of implications and impacts. Fox and Macleod (2021) note similar translational approaches through their action research project in Bristol. These different lenses can also be explained in terms of the practices of knowledge governance, to which we now turn.

\section{NARROW PRACTICES OF KNOWLEDGE GOVERNANCE}

The third set of challenges limiting the localization of the SDGs in England relates to the practices of governance in general, and knowledge politics, in particular. Despite variable holistic understandings amongst participants, the remit and function for the SDGs in both Greater Manchester and Sheffield reside within environmental departments. 'Sustainability' is framed as a question of climate change or carbon emissions and this is reflected in governance structures. Sheffield City Council's sustainability function is predominantly focused on environmental sustainability. The Council's declaration of a climate emergency during the course of the research affirmed and strengthened this focus. The Green City Partnership Board's remit, as the name suggests, has been focussed on carbon reduction and adaptive capacity. Whilst the Council is responsible for much other activity that falls within the UN's definition of sustainable development, it is not framed locally in this way:

"... we tend to talk about [sustainability] in terms of environmental
sustainability. So climate change, resilience, flood management,
... and sustainability is very much in that space, thinking about the
energy efficiency of buildings and those sorts of things. I think we
tend not to think about sustainability in terms of that very wide
set of things that the UN have identified, which isn't to say that we
don't talk about those things because we absolutely do, we just don't
badge it as sustainability." (Representative, Sheffield Green City
Partnership Board).

This 'badging' is a function of both how sustainability is governed and cross-cutting issues are addressed. Accordingly, engagement with the SDGs was, for some, a tactical approach to hold a mirror up to the need to transform governance processes and structures at the local level. The mobilization of the Goals as a political tool, was hoped to lead to different benefits, such as convening partnerships, designing projects, or working across policy teams to identify co-benefits and opportunities.

It is also a function of how data and expertise required to underpin the Goals are produced. International frameworks for measuring progress against such issues have been criticized for encapsulating 'targeted statistical manipulation' to show improving rather than worsening poverty and hunger trends (Hickel, 2016). This has given rise to an active debate over how to develop knowledge for sustainability (May and Perry, 2016) and measure sustainable development. The SDGs have been seen as a crucial way forward in measuring progress toward sustainability beyond GDP in the context of globalization, but this requires an 'integrated information system that straddles and balances the three pillars of economy, society and environment' (Macfeely, 2016: 790). Radermacher (2020) notes that, despite the vast international effort to produce, align and test for relevance and comparability across national settings, the effective use of such indicators is inseparable from necessary, extensive and complex social and political changes, meaning that expectations will not be met of a 'single, clear-cut statistical standard solution for the question of sustainable development metrics' (ibid: 108).

Because the SDG indicator framework is, by virtue of its international status, very high-level, adapting it for UK cities and identifying datasets at an appropriate level of granularity is difficult and resource intensive. Data which relate to the SDG indicators are collected at a number of scales-national, cityregional and local. Those indicators for which there is a formal city-regional capacity (such as transport) are easier to report on than those without (such as housing). During the 2000s, in the era of the Regional Development Agencies, intelligence units such as the Regional Intelligence Unit and Sustainability North West were in operation. At the time of the study, data within Greater Manchester was held and collected by different bodies, including New Economy and Transport for Greater Manchester, but also within local authorities. There was no single data / intelligence repository for Greater Manchester from which the indicators 
could be collectively reported, suggesting that the governance of data and spatial intelligence lags behind the changing economic geographies of England (Perry et al., 2013).

The Greater Manchester pilot study, which focussed on the availability of data to report on the Goals more than on policy alignment, looked specifically at the targets and indicators within SDG11 and found that no data were available, or was not collected, in specific areas. Examples include the proportion of the population that spends more than $30 \%$ of its income on accommodation; the ratio of land consumption rate to population growth rate at comparable scale; or the percentage of budget provided for maintaining cultural and natural heritage. Several of these data gaps are critical for holistic planning and implementation of the Goals but in GM, for instance, data on the area of open space as a proportion of total city space were reported as 'not collected'.

Local participants observed that city-level data are often not that useful, rather they are more interested in inequalities of outcome between different neighborhoods within their jurisdiction. There were several data gaps in official statistics at smaller geographic units; data were held at multiple levels of government and between public and private organizations; some data, such as on housing tenure, were inaccessible to local decision-makers due to the fragmentation of local housing markets between public, social and private providers. Data were also seen not to meet the SMART criteria (specific, measurable, attainable, realistic and time-limited). For instance, participants in our Greater Manchester workshop noted the lack of data on participation in planning, the high degrees of subjectivity in defining cultural heritage and the lack of specificity. As one person noted in relation to transport indicators: "buses run every 20 minutes" is not a useful indicator if they don't go where you want to go" (Greater Manchester workshop participant). A critical issue in the English context related to the relevance of particular definitions. A sense from some Greater Manchester officials that internationally defined categories pertaining to 'slums', 'informal settlements' and 'insecure housing tenure' were less applicable meant that issues of inadequate housing were underestimated in the city-region. Depending on the definition of 'safe and affordable housing, the percentage of the urban population living in slums or informal settlements was anywhere from 9 to $20 \%$.

As a result of these knowledge practices, it is unsurprising that our research found a lack of will to gather data, specifically in the context of resource constraint and uncertain national commitment. The SDG process was not reported to be of high relevance or priority to those participants we have engaged in Greater Manchester. In most cases, it was felt unlikely that any change in data collection, monitoring or evaluation would occur on account of the USDG, with little expectation that the USDG will have any meaningful impact in the city-region. Indeed, participants in the project felt that Greater Manchester was already ahead of the game in methods for data collection and in meeting minimum targets. Whilst our work highlighted the fractured nature of the evidence base against which the cityregion could measure its progress across multiple areas of public policy, the SDGs were not seen as a mechanism to overcome this challenge. Many participants felt that the city-region was already outperforming SDG targets in many areas. This also suggests a danger that a process such as the USDG could lead to complacency and 'business as usual' for those cities already performing well against the indicators. A framework like the SDGs may help to mobilize resources around particular issues but, as has been highlighted in the literature, may also reinforce existing power structures. This suggests the need for a reflexive and pragmatic use of Goals and indicators at the local level to enable cities to raise their game.

A strong caveat relates to the politics of data collection. At present, a series of issues inform what data are collected and analyzed and how they are deployed to inform policy. Often data are collected because someone, somewhere else in the public policy system, has asked for them-because it is a requirement placed upon local authorities to report. Given the ways in which data can be used to justify different political and ideological positions, this is not a neutral act. If data aren't collected on a particular issue because they are not required, then the issue to which they pertain may become 'invisible'. If there are no data on insecure housing or homelessness, does the issue become invisible? If the numbers of households living in fuel poverty aren't known, does that mean they don't exist? If we don't know about the distributional effects of climate change, does that mean there are none?

The Office of National Statistics (ONS) National Reporting Platform provides diverse open data at national level and some at sub-national level, though not at the level of granularity that local authorities need to inform local planning and decision-making. Even those cities already making progress in tracking the SDGschiefly Bristol, the first UK city to undertake a Voluntary Local Review of progress toward the SDGs (Fox and Macleod, 2019a,b, 2021), and London, through the work of the London Sustainable Development Commission (LSDC) - made similar observations to Sheffield participants about the difficulty of: (i) translating the SDG targets and indicators into locally-appropriate metrics; and (ii) identifying and accessing relevant data at the city and neighborhood levels.

The complexity, urgency and wickedness (Alford and Head, 2017) of sustainable development poses a central challenge to official statistics, including: the relevance of other geographies and scales of action beyond the nation state, the roles of public and private providers and the need for alternative ways of knowing and measuring to reveal the complexities and extent of entrenched social, economic and environmental inequalities. Official statistics give rise to metrics and indicators based on simplified assumptions, but we know that these do not hold when it comes to measuring progress on sustainable development requiring a 'data revolution' (Independent Expert Advisory Group on a Data Revolution for Sustainable Development, 2014).

With data fragmented and local authorities poorly organized for holistic, integrative work, it is not surprising that local leadership on the SDGs has been driven by other partners. In some UK cities, such as Bristol and Liverpool, local stakeholderled engagement has driven local political commitment to the SDGs despite their limited national visibility (Carden-Noad et al., 2017; Fox and Macleod, 2019a,b). In Bristol's case, this has been through a cross-sectoral SDG Alliance and university 
funding for an SDG Research and Engagement Associate; in Canterbury's case a citizens' SDG Forum and interest from local universities; in Liverpool's case a UN-recognized 'Local 2030 hub'; and in London's case the work of the London Sustainable Development Commission.

There is not, as yet, an equivalent catalyst in Sheffield or Greater Manchester. Policy and planning officials highlighted the lack of incentive for local government to take account of SDG targets that are neither mandatory nor commonly used as a benchmark. Participants emphasized that the SDGs focus on the role of businesses and civil society alongside national and local government and that the SDGs are more visible within the private sector, for example in setting corporate social responsibility agendas, or as a touchstone for sustainable business networks. Notably, there is also a key role for universities as partners or even lynchpins in cross-sectoral partnerships. As we have noted, without our research, for instance, there would have been no other engagement with the SDGs in either Greater Manchester or Sheffield during our study, whilst university researchers played key bridging roles in city responses, such as in Bristol (Fox and Macleod, 2021).

\section{DISCUSSION AND CONCLUSION}

Our research shows that co-dependence between national and local actors has produced an ambivalence about the localization of the Goals, characterized by low levels of local awareness, and devolution of responsibility without resource. This is no multi-level governance system where responsibilities are clearly divided and constituted across levels of government, but one that is fragmented and in flux. Efforts to map who is responsible for what are therefore thwarted by a complex and interactive governance 'mess' in which nothing remains settled enough, for long enough, for a clear map of responsibilities to appear. This feeds a partial holism, in which local authorities recognize the value of an integrative framework, but nonetheless need to make choices about which targets to cherry-pick and focus on, in a context of reduced resource. A further challenge to implementing the Goals relates to how sustainability, data and expertise are managed and governed, when institutional structures continue to militate against holistic or strategic policy development. This is reflective of wider governance and policy challenges against a background of 'austerity urbanism' (Peck, 2012). Notably, despite the differing governance arrangements in each placewith greater responsibilities devolved to Greater Manchester than Sheffield under the 'City Deals' process-there was little difference in the data, indicating the constraining impact of central government.

Our data suggest that, as a result of formal role and responsibility allocation across levels of governance, the space for strategic interventions is heavily circumscribed, leaving local authorities with a tactical choice over whether to commit stretched time and resources to localizing the SDGs. Some local authorities had already decided that there was a value in doing so. The Goals were not seen as perfect but could tell a local story which could inspire and motivate change and act to communicate on a wide range of topics with citizens and other stakeholders, as well as hopefully positioning the local authority favorably in international comparative terms. By translating the Goals and adapting them to what is most useful locally, some local authorities recognized that working with the Goals could be useful, and even be mobilized to produce wider governance and transformational change. However, co-ordination, resources and shared data were key prerequisites, leading to caution and concern, particularly in the context of austerity-stricken Brexit Britain. For some participants, the SDGs risk being yet another top-down imposition, as part of a system of targets and metrics, if they do not take local circumstances into account.

What tactics might then be deployed, in the face of these challenges, to extract value from the SDGs? Despite recognition that the global sustainability challenge is urgent, in view of competing priorities and limited resources, there is no a priori guarantee for English authorities that engagement with the SDGs is worthwhile. The challenges of co-dependent ambivalence, partial holism and narrow practices of knowledge politics mean that the value of the SDGs for local authorities is contingent and uncertain.

We therefore develop four value propositions (Figure 1) for local authority officers, political leaders and wider stakeholders. These suggest tactics for localizing the SDGs in the specific English multi-level governance context, focusing not on structural change but the development of relational practices.

The first value proposition is to make the SDGs real, by focusing on what is practicable within political, governance and resource constraints. Instead of feeling daunted or defeated by the potentially insurmountable magnitude of the challenge of comprehending, addressing and seeking to implement the entire SDG framework and all 17 Goals, comparing these to the local authority's existing monitoring, reporting and evaluation framework and variables will almost certainly demonstrate considerable commonality or overlap, with consistencies and inconsistencies or gaps. This will provide a useful starting point for considering further action, including whether the local authority will be better served by rigid adherence to current practice or switching or adapting at least partly to the globally comparable SDG framework. This, in turn, leads directly to the second proposition below.

The second value proposition is to make the SDGs relevant, by focusing on what is locally important. This involves deploying them to develop a common language across departments and enable cross-sectoral thinking and action. This could be done by identifying and making explicit how and what each department or sector contributes to broad common institutional objectives, such as promoting sustainable development (which equates to the SDG framework itself), tackling climate change and reducing poverty and social inequality. These activities will identify particular SDGs as being centrally important; these can then be augmented by identifying which SDGs and their respective targets and indicators apply to the key priorities of each department. This can prove valuable for enhancing the local authority's cohesion and efficiency of operation by building bridges across departments and sectors through reducing the constraint of conflicting professional and departmental 


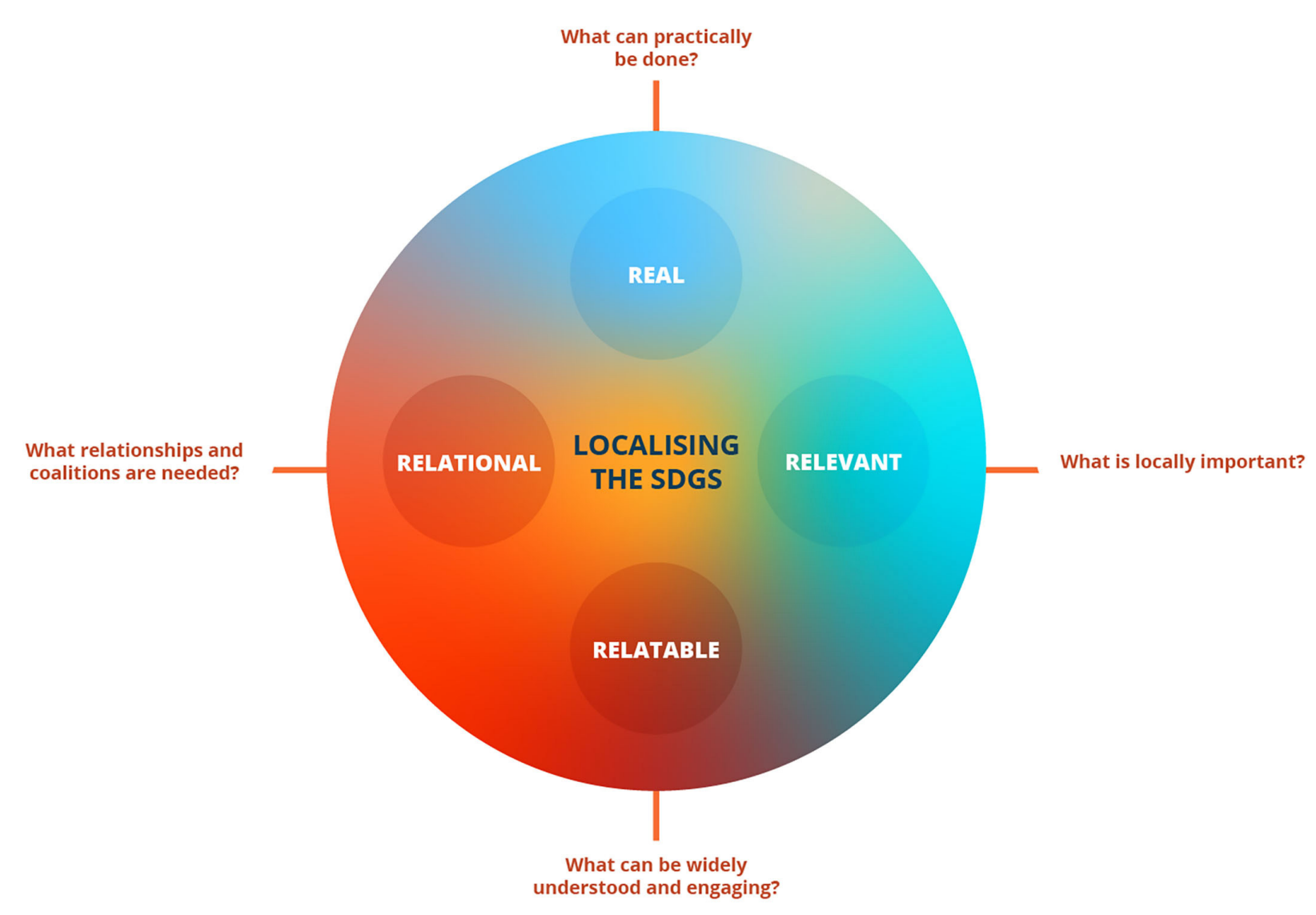

FIGURE 1 | Localizing the SDGs.

rationalities or 'ways of seeing and knowing' relating to a particular problem or task (Smit et al., 2021).

Such a relatively straightforward mapping exercise (Valencia et al., 2020) should also demonstrate that the local authority is already doing a fair amount to promote SDG achievement, albeit perhaps using somewhat different data or indicators. This is often important in gaining the buy-in of political leadership and officials, particularly if they can thereby appreciate how well their municipality is doing nationally or internationally. An informed cost-benefit decision, based on the pros and cons of retaining existing data and indicators as opposed to switching to those of the SDGs for ease of reporting and cross-city comparison, can then be made. Similarly, departments can then readily decide on the costs and benefits of adding additional targets and indicators to their reporting.

The third value proposition is to make the SDGs relatable, by focusing on what can be widely understood. This involves using the Goals as a public communication tool for a transformational narrative that can be a catalyst to wider engagement and participation. This has both internal and external dimensions. The former corresponds directly to the previous paragraph about the second value proposition. The latter builds on the same logic but involves translational work to explain the UN Agenda
2030 and the role of the SDGs into lay terms, highlighting their local relevance and value, what progress the city is already making and how well this compares with that of other local authorities intra- and internationally. One useful tool to galvanize engagement is to run a meaningful participatory process, ideally using co-production methods (Hemström et al., 2021), to identify strengths, gaps and priorities for different neighborhoods and stakeholder groups.

The fourth value proposition is to make the SDGs relational, by focusing on building coalitions and relationships. This builds on the second and third propositions above-which focused on internal local authority departments and on engaging wider publics respectively-by developing common knowledge infrastructures, fostering peer learning and forging co-production partnerships that bring different actors together to synergise expertise and work across sectors. Experience has demonstrated that such co-creation/-design/-production can substantially improve service delivery and identify different priorities and gaps for future investment to address the strategic priorities of sustainable development, tackling climate change and reducing poverty and social inequality (Perry et al., 2013; Durose and Richardson, 2016; Horvath and Carpenter, 2020; Simon et al., 2020). 
In conclusion, extracting locally relevant value from the SDGs is not a 'pure' task of perfect implementation. Each of our value propositions suggests tactics for how the SDGs can be useful to local authorities in light of the three challenges we identified through a series of fluid and inter-relational practices, rather than city-wide strategies. Importantly, these value propositions do not overcome the challenges identified; rather, they seek to work with them. This draws attention to the contingency, fluidity and complexity of multi-level governance arrangements, which cannot be fully described or codified. By making the Goals real, relevant, relatable and relational, our data suggest that even if English local authorities do not have the capacities, or resources, to fully implement the Goals, or measure progress against all of the targets, they can still deploy the SDGs tactically, as part of a suite of measures that can foster greater prosperity, equality and justice at the local level.

\section{DATA AVAILABILITY STATEMENT}

The original contributions presented in the study are included in the article/supplementary material, further inquiries can be directed to the corresponding author/s.

\section{ETHICS STATEMENT}

The studies involving human participants were reviewed and approved by the University of Sheffield. The participants provided their written informed consent to participate in this study.

\section{REFERENCES}

Alford, J., and Head, B. (2017). Wicked and less wicked problems: a typology and a contingency framework. Policy Soc. 36, 397-413. doi: 10.1080/14494035.2017.1361634

Allen, C., Metternicht, G., and Wiedmann, T. (2018). Initial progress in implementing the Sustainable Development Goals (SDGs): a review of evidence from countries. Sustain. Sci. 13, 1453-1467. doi: 10.1007/s11625-018-0572-3

Ansuategi, A., Greno, P., Houlden, V., Markandya, A., Onofri, L., Picot, H., et al. (2015). The Impact of Climate Change on the Achievement of the Post-2015 Sustainable Development Goals. Available online at: https://assets.publishing. service.gov.uk/media/57a0897bed915d622c000233/Impact-of-climate-onSDGs_Technical-Report-CDKN.pdf (accessed July 26, 2021).

Arfvidsson, H., Simon, D., Oloko, M., and Moodley, N. (2017). 'Engaging with and measuring informality in the proposed Urban Sustainable Development Goal', Afr. Geogr. Rev. 36, 100-114. doi: 10.1080/19376812.2015.1130636

Ayres, S., Flinders, M., and Sandford, M. (2018). Territory, power and statecraft: understanding English devolution. Region. Stud. 52, 853-864. doi: 10.1080/00343404.2017.1360486

Bache, I., and Flinders, M. (Eds). (2004). Multi-Level Governance. Oxford: Oxford University Press. doi: 10.1093/0199259259.001.0001

Barnett, C., and Parnell, S. (2016). Ideas, implementation and indicators: epistemologies of the post-2015 urban agenda. Environ. Urban. 28, 87-98. doi: 10.1177/0956247815621473

Blunkett, D., Flinders, M., and Prosser, B. (2016). Devolution, evolution, revolution ... democracy? what's really happening to english local governance? Polit. Quart. 87, 553-564. doi: 10.1111/1467-923X.12282

Blythe, J., Silver, J., Evans, L., Armitage, D., Bennett, N. J., Moore, M. L., et al. (2018). The dark side of transformation: latent risks in contemporary sustainability discourse. Antipode 50, 1206-1223. doi: 10.1111/anti.12405

\section{AUTHOR CONTRIBUTIONS}

BP led the GM pilot study. NTB and KD led data collection on the Sheffield study. KD, NTB, and BP organized and analyzed the UK workshop with UKSSD. The first draft of a manuscript was written by NTB and KD and subsequent revisions, analysis and integration of all relevant data undertaken by BP with contributions by DS. All authors contributed to the article and approved the submitted version.

\section{FUNDING}

This research has been funded by the Mistra Foundation for Strategic Environmental Research, via the Mistra Urban Futures Center. The UK workshop with UKSSD was funded by the Grantham Centre for Sustainable Futures. The Gothenburg Center for Sustainable Development supported the open access publication fee.

\section{ACKNOWLEDGMENTS}

We would like to acknowledge researchers Alex Wharton and Louise Marix Evans from the Greater Manchester pilot study, Sandra Valencia for leading the international comparative study, and Emily Auckland for co-organizing the UK SDG workshop. We would also like to thank all participants in the GM and Sheffield studies and the UK SDG workshop for their contributions.

Bryant, A., and Charmaz, K. (eds). (2010). The Sage Handbook of Grounded Theory. London: Sage.

Bulkeley, H. (2019). Accomplishing Climate Governance. Cambridge: Cambridge University Press.

Carden-Noad, S., Macleod, A., Skidmore, T., and Turner, E. (2017). Bristol and the UN Sustainable Development Goals: An Assessment of Strategic Alignment, Data, and Delivery Gaps in Bristol. Bristol: University of Bristol for Bristol Green Capital Partnership and Bristol City Council. Available online at: https://bristolgreencapital.org/wp-content/uploads/2017/07/UoB_ SDGs-Bristol-report_final_20-Jul-2017.pdf (accessed July 26, 2021).

Carter, N. (2008). Combating climate change in the UK: challenges and obstacles. Polit. Quart. 79, 194-205. doi: 10.1111/j.1467-923X.2008. 00913.x

Castán Broto, V. (2017). Urban governance and the politics of climate change. World Dev. 93, 1-15, doi: 10.1016/j.worlddev.2016.12.031

Coleman, A., Segar, J., and Checkland, K. (2016). The devolution project in greater manchester: introduction to the special issue. Representation 51, 377-384. doi: 10.1080/00344893.2016.1165496

Colomb, C., and Tomaney, J. (2016). Territorial politics, devolution and spatial planning in the UK: results, prospects, lessons. Plann. Pract. Res. 31, 1-22. doi: 10.1080/02697459.2015.1081337

Croese, S., Green, C., and Morgan, G. (2020). Localizing the sustainable development goals through the lens of urban resilience: lessons and learnings from 100 resilient cities and Cape Town. Sustainability 12:550. doi: $10.3390 /$ su12020550

de Certeau, M. (1984). The Practice of Everyday Life. Translated by Steven F. Rendell. Berkeley: University of California.

Durose, C., and Richardson, L., (eds). (2016). Designing Public Policy for Co-production: Theory, Practice and Change. Bristol: Policy Press. doi: 10.1332/policypress/9781447316695.001.0001 
Fox, S., and Macleod, A. (2019a). Aligning Bristol's One City Plan with the SDGs. Local Data Action Solutions Initiative. Available online at: https://staticl.squarespace.com/static/5b4f63e14eddec374f416232/ t/5cb648ab71c10b68661d288f/1555450031449/LDASI-England-Bristol_ April19.pdf (accessed July 26, 2021).

Fox, S., and Macleod, A. (2019b). Bristol and the SDGs: A Voluntary Local Review of Progress 2019. University of Bristol. Available online at: https://researchinformation.bris.ac.uk/en/publications/bristol-and-the-sdgs-a-voluntarylocal-review-of-progress-2019 (accessed July 26, 2021).

Fox, S., and Macleod, A. (2021). Localizing the SDGs in cities: reflections from an action research project in Bristol, UK. Urban Geogr. 78, 529-540. doi: 10.1080/02723638.2021.1953286

Fuller, C., and West, K. (2017). The possibilities and limits of political contestation in times of 'urban austerity'. Urban Stud. 54, 2087-2106. doi: 10.1177/0042098016651568

Graute, U. (2016). Local authorities acting globally for sustainable development. Reg. Studs. 50, 1931-1942. doi: 10.1080/00343404.2016.1161740

Greene, G., and Meixell, B. (2017). Hacking the Sustainable Development Goals. Can US Cities Measure Up? Available online at: Hacking the Sustainable Development Goals (urban.org) (accessed July 26, 2021).

Guest, G., MacQueen, K., and Namey, E. (2012). Applied Thematic Analysis. Thousand Oaks CA: Sage Publications Inc. doi: 10.4135/9781483384436

Hajer, M., Nilsson, M., Raworth, K., Bakker, P., Berkhout, F., de Boer, Y., et al. (2015). Beyond cockpit-ism: four insights to enhance the transformative potential of the sustainable development goals. Sustainability 7, 1651-1660. doi: $10.3390 /$ su7021651

Hambleton, R. (2017). The super-centralisation of the English state - Why we need to move beyond the devolution deception. Local Econ. 32, 3-13. doi: 10.1177/0269094216686296

Hastings, A., Bailey, N., Bramley, G., and Gannon, M. (2017). Austerity urbanism in England: the 'regressive redistribution' of local government services and the impact on the poor and marginalised. Environ. Plann. A 49, 2007-2024. doi: 10.1177/0308518X17714797

Hemström, K., Simon, D., Palmer, H., Perry, B., and Polk, M. Eds. (2021). Transdisciplinary Knowledge Co-production for Sustainable Cities. Rugby, CA: Practical Action. doi: 10.3362/9781788531481

Hersperger, A., Bürgi, M., Wende, W., Bacău, S., and Grădinau, S. (2020). Does landscape play a role in strategic spatial planning of European urban regions? Landsc.and Urban Plann. 194:103702. doi: 10.1016/j.landurbplan.2019.103702

Hickel, J. (2016). The true extent of global poverty and hunger: questioning the good news narrative of the Millennium Development Goals. Third World Quart. 37, 749-767. doi: 10.1080/01436597.2015.1109439

Hickson, C. (2015). Bringing the Goals Home. Implementing SDGs in the UK. London: Bond for International Development.

Hooghe, L., and Marks, G. (2003). Unravelling the central state, but how? Types of multi-level governance. Am. Polit. Sci. Rev. 97, 233-243. Available online at: https://www.jstor.org/stable/3118206

Horvath, C., and Carpenter, J. (eds). (2020). Co-creation in theory and practice: exploring creativity in the Global North and South. Bristol: Policy Press. doi: 10.1332/policypress/9781447353959.001.0001

House of Commons (2019). UK Voluntary National Review on the Sustainable Development Goals. Number CDP-0141. London: House of Commons Library.

House of Commons Environmental Audit Committee (2019). Sustainable Development Goals in the UK Follow Up: Hunger, malnutrition and food insecurity in the UK. Thirteenth report of session 2017-2019. HC1491. London, House of Commons.

House of Commons Environmental Audit Committee. (2017). Sustainable Development Goals in the UK. Ninth report of session 2016-2017. HC596. London: House of Commons.

House of Commons International Development Committee (2016). UK Implementation of the Sustainable Development Goals. First report of session 2016-2017. HC103. London: House of Commons.

Hulme, M., and Turnpenny, J. (2004). Understanding and managing climate change: the UK experience. Geogr. J. 170, 105-115. doi: 10.1111/j.0016-7398.2004.00112.x

IIED for the Cities Alliance (2015). Transforming our World: The 2030 Agenda for Sustainable Development. A Critical Analysis of the Role of Cities and Local Governments in the Global Agendas. Available online at https://
www.citiesalliance.org/sites/default/files/2030Agenda-iied.pdf (accessed July 26, 2021).

Independent Expert Advisory Group on a Data Revolution for Sustainable Development (2014). A World that Counts - Mobilising the Data Revolution for Sustainable Development. Available online at: http://www.undatarevolution. org/wp-content/uploads/2014/12/A-World-That-Counts2.pdf (accessed January 5, 2021).

Jones, M., and Ward, K. (2002). Excavating the logic of British urban policy: neoliberalism as the 'crisis of crisis management.' Antipode 34.3, 473-494. doi: 10.1002/9781444397499.ch6

Joss, S., Cook, M., and Dayot, Y. (2017). Smart cities: towards a new citizenship regime? A discourse analysis of the british smart city standard. J. Urban Technol. 24, 29-49. doi: 10.1080/10630732.2017.1336027

Klopp, J., and Petretta, D. (2017). The urban sustainable development goal: indicators, complexity and the politics of measuring cities. Cities 63, 92-97. doi: 10.1016/j.cities.2016.12.019

Koch, F., and Ahmad, S. (2018). "How to measure progress towards an inclusive, safe, resilient and sustainable city? Reflections on applying the indicators of sustainable development goal 11 in Germany and India," in eds S. Kabisch, F. Koch, E. Gawel, A. Haase, S. Knapp, K. Krellenberg et al., Urban Transformations: Sustainable Urban Development Through Resource Efficiency, Quality of Life and Resilience (Cham: Springer International Publishing), 77-90. doi: 10.1007/978-3-319-59324-1 5

Leck, H., and Simon, D. (2013). Fostering multiscalar collaboration and cooperation for effective governance of climate change adaptation. Urban Stud. 50, 1221-1238. doi: 10.1177/0042098012461675

Leck, H., and Simon, D. (2018). Local authority responses to climate change in South Africa: The challenges of transboundary governance. Sustainability 10:2542. doi: 10.3390/su10072542

Macfeely, S. (2016). The continuing evolution of official statistics: some challenges and opportunities. J. Official Stat. 32, 789-810. doi: 10.1515/jos-2016-0041

May, T., and Perry, B. (2016). Knowledge for just sustainability. Local Environ. 22, 23-35. doi: 10.1080/13549839.2016.1233527

May, T., and Perry, B. (2018). Cities and the Knowledge Economy: Promise, Politics and Possibility. London; New York, NY: Routledge.

McGowan, P. J. K., Stewart, G. B., Long, G., Grainger, M. J. (2018). An imperfect vision of indivisibility in the Sustainable Development Goals. Nat. Sustain. 2:1. doi: 10.1038/s41893-018-0190-1

Nilsson, M., Griggs, D., Visbeck, M. (2016). SDG interactions. Nature 534, 320-322. doi: 10.1038/534320a

Patel, Z., Greyling, S., Simon, D., Arfvidsson, H., Moodley, N., Primo, N., et al. (2017). Local responses to global sustainability agendas: learning from experimenting with the urban sustainable development goal in Cape Town. Sustain. Sci. 12, 785-797. doi: 10.1007/s11625-017-0500-y

Peck, J. (2012). Austerity urbanism: American cities under extreme economy. City 16, 626-655. doi: 10.1080/13604813.2012.734071

Perry, B., and Atherton, M. (2017). Beyond critique: the value of coproduction in realising just cities? Local Environ. 22, 36-51. doi: 10.1080/13549839.2017.1297389

Perry, B., May, T., Marvin, S., and Hodson, M. (2013). "Rethinking sustainable knowledge-based urbanism through active intermediation: what knowledge and how?", in eds H. T. Andersen and R. Atkinson, The Production and Use of Urban Knowledge: European Experiences (Dordrecht: Springer), 151-168. doi: 10.1007/978-90-481-8936-6_8

Perry, B., Patel, Z., Noren Bretzer, Y., and Polk, M. (2018). Organising for coproduction: local interaction platforms for urban sustainability. Polit. Govern. 6, 189-198. doi: 10.17645/pag.v6i1.1228

Perry, B., and Russell, B. (2020). "Participatory cities from the 'Outside In': the value of comparative learning," In eds D. Simon, H. Palmer, and J. Riise, Comparative Urban Research From Theory To Practice (Bristol: Policy Press), 133-155. doi: 10.2307/j.ctv10tq4cj.13

Polk, M. (ed). (2015). Co-producing Knowledge for Sustainable Cities: Joining Forces for Change. London: Routledge. doi: 10.4324/9781315748030

Radermacher, W. (2020). Official Statistics 4.0. Verified Facts for People in the 21st Century. London: Springer. doi: 10.1007/978-3-03031492-7

Reckien, D., Creutzig, F., Fernandez, B., Lwasa, S., Tovar-Restrepo, M., Satterthwaite, D. (2017). Climate change, equity and the Sustainable 
Development Goals: an urban perspective. Environ. Urban. 29, 159-182. doi: $10.1177 / 0956247816677778$

Robin, E., Acuto, M. (2018). Global urban policy and the geopolitics of urban data. Polit. Geogr. 66, 76-87. doi: 10.1016/j.polgeo.2018.08.013

Rudd, A., Simon, D., Cardama, M., Birch, E. L., and Revi, A. (2018). "The UN, the urban sustainable development goal, and the New Urban Agenda," in eds T. Elmqvist, X. Bai, N. Frantzeskaki, C. Griffith, D. Maddox, T. McPhearson, et al., Chapter 9, Urban Plane (Cambridge: University Press, Cambridge), 180-196. Available online at: http://www.cambridge.org/ 9781107196933 (accessed November 17, 2018).

Sánchez Rodríguez, R., Ürge-Vorsatz, D.i., Barau, A. S. (2018). Sustainable Development Goals and climate change adaptation in cities. Nat. Clim. Chang. 8, 181-183. doi: 10.1038/s41558-018-0098-9

Simon, D., Arfvidsson, H., Anand, G., Bazaz, A., Fenna, G., Foster, K., et al. (2016). Developing and testing the Urban Sustainable Development Goal's targets and indicators - a five-city study. Environ. Urban. 28, 49-63. doi: $10.1177 / 0956247815619865$

Simon, D., Griffith, C., and Nagendra, H. (2018). "Rethinking urban sustainability and resilience," in eds T. Elmqvist, X. Bai, N. Frantzeskaki, C. Griffith, D. Maddox, T. McPhearson, et al., Chapter 7, Urban Planet (Cambridge: University Press, Cambridge), 149-162. Available online at: http://www. cambridge.org/9781107196933 (accessed November 17, 2018).

Simon, D., Palmer, H., and Riise, J. (eds). (2020). Comparative Urban Research From Theory to Practice. Bristol: Policy Press. doi: 10.2307/j.ctv10tq4cj

Smit, W., Simon, D., Durakovic, E., Dymitrow, M., Haysom, G., Hemström, K., et al. (2021). The challenge of conflicting rationalities about urban development: experiences from Mistra Urban Futures' transdisciplinary urban research. TRIALOG 137, 31-37.

Stoecker, R., and Avila, E. (2020). From mixed methods to strategic research design. Int. J. Soc. Res. Methodol doi: 10.1080/13645579.2020.1799639

Sultana, F. (2018). An(Other) geographical critique of development and SDGs. Dialog. Hum Geogr. 8, 186-190. doi: 10.1177/20438206187 80788

Swain, R. B. (2017). "A critical analysis of the Sustainable Development Goals," in ed W. L. Filho, Handbook of Sustainability Science and Research (Cham: SpringerNature), 341-355. doi: 10.1007/978-3-319-63007-6_20

Tait, M., and Inch, A. (2015). Putting localism in place: conservative images of the good community and the contradictions of planning reform in England. Plann. Pract. Res. 31, 174-194. doi: 10.1080/02697459.2015.1104219

Taylor, M. (2017). "Making policy Q and A," in ed A. Burnham. Metropolis, Autumn/Winter Manchester: Metropolis, 22-27.

Taylor-Gooby, P. (2012). Beveridge overboard? How the UK government is using the crisis to permanently restructure the welfare State. Intereconomics 47, 224-229. doi: 10.1007/s10272-012-0422-y

UK Stakeholders for Sustainable Development (UKSSD) (2018). Measuring Up: How the UK Is Performing on the UN Sustainable Development Goals. London: UKSSD.
UN (2017). New Urban Agenda. New York, NY. Available online at: https:// unhabitat.org/sites/default/files/2019/05/nua-english.pdf.

U. N. Habitat (2020). World Cities Report 2020: The Value of Sustainable Urbanization. Nairobi: U. N. Habitat. Available online at: https://unhabitat.org/ sites/default/files/2020/10/wcr_2020_report.pdf (accessed November 5, 2020).

Valencia, S., Simon, D., Croese, S., Davison, A., Diprose, K., Krishnaswami Srinivas, A., et al. (2021) "Urban climate resilience and its link to global sustainability agendas," in ed R. Brears, Palgrave Handbook of Climate Resilient Societies, Chapter 131-1 (Cham: SpringerNature) p. 28. doi: 10.1007/978-3-030-32811-5_131-1

Valencia, S., Simon, D., Croese, S., Nordqvist, J., Oloko, M., Sharma, T., et al. (2019). Adapting the sustainable development goals and the new urban agenda to the city level: initial reflections from a comparative research project. Int. J. Urban Sust. Dev. 11, 4-23. doi: 10.1080/19463138.2019.15 73172

Valencia, S. C., Simon, D., Croese, S., Diprose, K., Nordqvist, J., Oloko, M., et al. (2020) "Internationally initiated projects with local coproduction: urban sustainable development goal project," in eds D. Simon, H. Palmer, and J. Riise, Chapter 6, Comparative Urban Research From Theory to Practice; Co-production for sustainability (Bristol: Policy Press), 113-131. Available online: http://www.oapen.org/search? identifier $=1007874 \quad$ (accessed May 15, 2020). doi: 10.2307/j.ctv10t q4cj.12

Waite, D., Maclennan, D., and O'Sullivan, T. (2013). Emerging city policies: devolution, deals and disorder. Local Econ. 28, 770-85. doi: $10.1177 / 0269094213500122$

Yin, R. K. (2014) Case Study Research: Design and Methods, 5th Edn. Thousand Oaks, CA: Sage.

Conflict of Interest: The authors declare that the research was conducted in the absence of any commercial or financial relationships that could be construed as a potential conflict of interest.

Publisher's Note: All claims expressed in this article are solely those of the authors and do not necessarily represent those of their affiliated organizations, or those of the publisher, the editors and the reviewers. Any product that may be evaluated in this article, or claim that may be made by its manufacturer, is not guaranteed or endorsed by the publisher.

Copyright (c) 2021 Perry, Diprose, Taylor Buck and Simon. This is an open-access article distributed under the terms of the Creative Commons Attribution License (CC $B Y)$. The use, distribution or reproduction in other forums is permitted, provided the original author(s) and the copyright owner(s) are credited and that the original publication in this journal is cited, in accordance with accepted academic practice. No use, distribution or reproduction is permitted which does not comply with these terms. 